\title{
Vol. 444: 239-249, 2012 \\ Contrasting effects of food quality and quantity on a marine top predator
}

\author{
M. $\operatorname{Kadin}^{1, *}$, H. Österblom ${ }^{1,2}$, J. Hentati-Sundberg ${ }^{1}$, O. Olsson ${ }^{1}$ \\ ${ }^{1}$ Stockholm Resilience Centre, Stockholm University, 10691 Stockholm, Sweden \\ ${ }^{2}$ Baltic Nest Institute, Stockholm Resilience Centre, Stockholm University, 10691 Stockholm, Sweden
}

\begin{abstract}
Overfishing of predatory fish has contributed to an increase in forage-fish stocks. At the same time, a rising demand for forage fish to supply fishmeal markets, in combination with climate change, has put strong pressure on these stocks, and this, in turn, has had an impact on marine top predators. We examined how inter-annual variation in food quality (sprat Sprattus sprattus weight-at-age) and quantity (sprat abundance) influenced Baltic Sea common murres Uria aalge during chick-rearing. Fledging success, i.e. survival from hatching to fledging, showed a positive relationship with food quality, but we found no effect of food quantity. We found no relationship between food quality and parental behaviour or chick feeding parameters, but a negative relationship between food quantity and trip duration. Our data indicate that there was room for parental birds to increase their effort to compensate for reduced food quality, but we found no signs of such compensation. We analysed different types of fish and seabird life-history data to separate effects of food quantity and quality on a top predator. Understanding such effects can contribute to clarifying causes and consequences for observed changes in life-history parameters and population dynamics of top predators.
\end{abstract}

KEY WORDS: Junk food - Trophic cascades - Ecosystem approach · Environmental change · Climate change $\cdot$ Alcidae $\cdot$ Common guillemot

\section{INTRODUCTION}

Fishing pressure and climate variations can have substantial effects on the dynamics of fish stocks (Ludwig et al. 1993, Jackson et al. 2001, Cheung et al. 2009, Möllmann et al. 2009). Limited capacity to expand capture fisheries (Sethi et al. 2010) is increasing the demand to expand aquaculture (Pauly et al. 2003, FAO 2010), where forage fish are an important feed source (Naylor et al. 2009). This may create conflicts between human needs and forage-fish predators (Naylor et al. 2000, Deutsch et al. 2007, Alder et al. 2008). Fisheries are increasingly managed with an ecosystem approach where these conflicts need to be taken into account. Dealing with such trade-offs, however, requires adequate information about the biological characteristics of the system, including knowledge of cascading impacts on non-target populations (e.g. Jackson et al. 2001, Frank et al. 2005, Casini et al. 2009).

The dynamics of forage-fish stocks are likely to imply changes in quantity and quality of food for top predators, such as marine mammals and seabirds. Several studies have shown links between changes in prey species and life-history parameters and population dynamics in marine mammals and seabirds (reviewed in Piatt et al. 2007, Österblom et al. 2008). The likely effects of changes in quantity are intuitive and relatively well studied. More recent studies have revealed that food quality can also be an important parameter for some marine top predators (Österblom et al. 2008). The 'junk-food hypothesis' predicts neg- 
ative impacts on predators from reduced prey quality and was originally suggested as an explanation for the decline of Steller sea lion Eumetopias jubatus in the Gulf of Alaska (Alverson 1992). The hypothesis has been questioned, but is discussed as one of several likely mechanisms contributing to the lack of recovery in this population (Trites \& Donnelly 2003, Fritz \& Hinckley 2005, Sigler et al. 2009).

The capacity of predators to adapt to changing environmental conditions is influenced by species sensitivity (Furness \& Tasker 2000) and ecosystem characteristics (e.g. availability of alternative prey). For instance, breeding success of North Sea seabirds is associated with prey biomass for species bringing multiple prey items to the chicks, but with length of preferred prey for common murres Uria aalge that feed their chicks with individual fish (Frederiksen et al. 2006). A breeding failure of North Sea murres was also partly explained by diet shifts and low quality of prey (Wanless et al. 2005). However, at the same time, food availability decreased, and the combined impact resulted in unprecedented low breeding success during several consecutive breeding seasons (Ashbrook et al. 2008, 2010). Top predators may thus be influenced simultaneously by changes in both food quantity and quality, and this may affect different components of reproduction and survival.

How changes in quantity and quality in different directions affect seabirds and how seabirds adjust their behaviour in response to such changes is rarely known. The significance of food quality is often confounded by concurrent reductions in food availability due to e.g. fishery- or climate-induced changes in spatial, temporal or total abundance.

Large-scale changes in the Baltic Sea ecosystem have influenced the conditions for seabirds in the region and provide a unique opportunity to study the importance of food quantity and quality as factors that may influence different life-history characteristics. Favourable conditions led to a cod Gadus morhua boom in the late 1970s (Eero et al. 2011), resulting in high catches and investments in the cod fishery in the 1980s. However, overfishing and unfavourable reproductive conditions led to a collapse of the cod stock, which allowed their main prey, sprat Sprattus sprattus, to increase dramatically (MacKenzie et al. 2002, Möllmann et al. 2009). Warmer winters since the end of the 1980s were at the same time beneficial for sprat reproduction (MacKenzie \& Köster 2004, Möllmann et al. 2008). Biomass and community composition of zooplankton changed following the increased predation by sprat and as a result of climatic drivers (Alheit et al. 2005).
Density-dependent mechanisms resulted in decreased body mass and condition of sprat and herring Clupea harengus in the 1990s (Casini et al. 2006, 2010). Apparently, these changes influenced the common murre, for which fledging mass dropped during the period with a very large sprat stock (Österblom et al. 2001, 2006), suggesting that prey quality may affect important life-history parameters of this population. However, common murre populations in the region appear stable or increasing, possibly as a result of the increased prey abundance (Staav 2009, Hjernquist \& Hjernquist 2010).

The sprat stock has fluctuated at slightly lower levels during recent years, due to intense fishery and possibly predation from an increasing cod stock (ICES 2010). Meanwhile, sprat body mass has increased slightly (ICES 2010). In this context, we investigate the role of food quantity (i.e. sprat abundance) and quality (sprat weight-at-age) for chickrearing common murres on Stora Karlsö, Baltic Sea, by studying variation in fledging success. We use parent behavioural responses and chick feeding parameters in an attempt to elucidate mechanisms influencing relationships with quantity and quality. This case is particularly useful for studying the junkfood hypothesis, since the effects of reduced food quality can be studied separately from reduced food abundance, which is otherwise rarely the case.

\section{MATERIALS AND METHODS}

\section{Focal species and study site}

The common murre is a long-lived pursuit-diving seabird that breeds in colonies off temperate coasts of the northern hemisphere. Stora Karlsö (57 $17^{\prime} \mathrm{N}$, $17^{\circ} 58^{\prime}$ E) holds the largest colony in the Baltic Sea, $\sim 10000$ pairs, and emigration from Stora Karlsö has been assessed as important for the smaller colonies in the Baltic Sea (Hario 1982, Lyngs 1993, Österblom et al. 2004). On Stora Karlsö, egg-laying starts in late April or early May. After about $30 \mathrm{~d}$ of incubation, the single egg hatches. Both parents take part in incubation and chick-rearing, and the chick is attended by one parent while the other forages. Parents spend some time together on the breeding ledge, and this time can be re-allocated to foraging, providing a buffer against adverse conditions and thus reflecting conditions experienced by parents (Burger \& Piatt 1990). The common murre is a highly specialised feeder and a single-prey loader (Bradstreet \& Brown 1985), i.e. when provisioning its chick, the parent 
brings it only a single prey item. Both the size and energy content of prey items are thus important for the chick. Chicks leave the Stora Karlsö colony at an average age of 19 d (Hedgren \& Linnman 1979) to $21 \mathrm{~d}$ (SD: $2.3 \mathrm{~d}$; range: 15 to $30 \mathrm{~d}$; data from 1999 to 2009) weighing 20 to $25 \%$ of adult body mass (Hedgren \& Linnman 1979, Österblom et al. 2001, 2006, Österblom \& Olsson 2002, present study). In the present paper, fledging is considered to occur at colony departure, and the young birds are referred to as juveniles after this point.

\section{Fledging success}

Observations of egg-laying, hatching and fledging were conducted in the period 1974-77 (Hedgren 1980), and in 1999 plus 2005-09 (present study). The methodology of the later studies was sufficiently similar to the method employed by Hedgren (1980) to allow direct comparisons. Daily observations were made at a distance of 4 to $30 \mathrm{~m}$ using binoculars, starting in late April or early May. Studies covered 82 to 270 breeding pairs annually and ended July 10 in 1999, July 4 in 2005-06 and July 16 in 2007-09. Birds that still had an egg or a chick younger than $15 \mathrm{~d}$ on the final day of the study were excluded from the analyses (0 to 3 pairs per year, except for 2005: 6 pairs). Analyses focused on survival of chicks from hatching to fledging (hereinafter fledging success), as our preliminary analysis indicated that variation in egg survival (from laying to hatching) was high, possibly due to variation in levels of hazardous substances affecting hatching rates (e.g. perfluorooctane sulfonic acid [PFOS]; Holmström et al. 2005) and egg predation from herring gulls Larus argentatus (Österblom \& Olsson 2002, authors' pers. obs.). Fledging occurs at night and is thus difficult to observe. Chicks that disappeared after reaching the age of $15 \mathrm{~d}$ were assumed to have fledged successfully. Reported estimates include chicks from both first-laid and replacement eggs. The annual proportion of chicks hatched from replacement eggs was $4.1 \%$ (range: 0 to $10.6 \%$ ). The within-season fledging success was similar in the 2 groups, but, when combining data from all years, chicks from replacement eggs had lower fledging success than chicks from first-laid eggs $\left(\chi^{2}=83.1\right.$, df $\left.=1, \mathrm{p}<0.001\right)$. However, data from first-laid eggs and pooled data yielded similar estimates. As we consider the overall fledging success to be most relevant, it is these results which are presented here.

\section{Chick provisioning}

Studies of chick feeding were conducted in 1998, 2002 and 2005-09 through 3 annual dawn-to-duskwatches (19 to $20 \mathrm{~h}$ ) during the period June 9 to 23 . Data were collected on 8 to 25 pairs per watch (median and mean: 18 pairs). The focal ledge hosted 34 to 38 pairs during the study period. Of all the observed pairs, 50 to $75 \%$ had at least 1 ringed or bridled member (morph with white orbital ring and auricular groove). Observations were made from above at a distance of $3.5 \mathrm{~m}$. In 2002, the focal ledge was filmed and feeding data were compiled from this material, but no data on time budgets were extracted. Direct observations were made in the field in the other years. Fish identified as clupeids were included in the analyses of fish size. From 2002 to 2005, whole fish were allocated to 1 of 4 size categories, using parent bill length (culmen, mean length: $49 \mathrm{~mm}$; Peterz \& Blomqvist 2010) as a reference. The size categories corresponded to fish of ca. $\leq 2,2 \frac{1}{3}, 2^{2} \frac{2}{3}$ and $\geq 3$ bill lengths. Comments in the field notes on very small and very large fish, respectively, combined with photographs, allowed us to justify the assumption that fish size category 1 is equal to a 2-bill-length-sized fish for clupeids. Size category 4 includes a few fish that were substantially larger than 3 bill lengths. Reported values may thus be biased low for fish sizes measured in bill length. Murres can hold fish at different depths in their throat, which may affect the accuracy of the size assessment. However, Elliott et al. (2008), investigating bias in murre provisioning data, found a robust relationship between estimated and actual length. Further, provided that the depth at which a fish of a particular size is held has no trend over time, and that there is constant variation, annual means and distribution in size categories should not be affected. We thus consider it justified to use the data for comparisons between years.

We recorded successful foraging (i.e. parent returning with a fish), successful feeding (chick observed swallowing the fish or no fish at the nest site on subsequent checks) and the feeding frequency, based on successful feeds, for each pair. The length of time both parents were present at the ledge (i.e. time spent with mates) as well as trip duration were measured by noting the time parents arrived or left, but such periods were excluded from the analyses if uncertainty of a time of arrival or departure was $>5 \mathrm{~min}$. Analysis of the full data set revealed that number of fish fed per day and fish size were strongly influenced by the age of the chick (ANOVA using chick age in 
3-day classes of 1-3 d, 4-6 d, etc. as an explanatory variable). To avoid biases caused by intra- and interannual variation in median age of chicks, chicks in age classes that received significantly fewer fish per day or significantly smaller fish were excluded from further analysis (no age class was fed significantly more often or received significantly larger fish). No influence of chick age on trip duration was found, and hence data from all pairs were used. Mean and median values as well as visual examination of patterns in data from each watch were used to assess other potential intra-annual trends and sources of bias, but no factor other than chick age could be identified as influential, and so data from all 3 annual watches were pooled (with the exception of percentage time spent with mates during a watch).

\section{Chick diet}

Hedgren (1976) and Lyngs \& Durinck (1998) illustrated that, in the Baltic Sea, a large proportion $(>90 \%)$ of common murre chick and adult diet consists of sprat. Types of fish were recorded in the chick provisioning studies described in the previous section and additional observations were made in June 2004. The data reveal that 91.7 to $98.6 \%$ of all fish brought to chicks on Stora Karlsö in the 8 different study years were clupeids (Table A1 in Appendix 1). The majority of the clupeids were presumably sprat since sprat in relation to herring was more abundant from 1998 to 2009 (Möllmann et al. 2005) than during the studies of Hedgren (1976) and Lyngs \& Durinck (1998). Further, all of the few (around 10) miscellaneously collected prey items were sprat. We thus assume that chick diet consisted mainly of sprat throughout the study period.

\section{Fish data}

Estimates of sprat abundance and mean weight-atage from 1974 to 2009 were obtained from the annual assessment made by the ICES Baltic Fisheries Assessment Working Group (WGBFAS; ICES 2010). Sprat weight-at-age is calculated from samples from commercial landings obtained throughout the year (ICES 2010). The mean weights of sprat of different age classes show similar inter-annual trends (ICES 2010), and we primarily used weight-at-age-4 in our analyses, because the mean body mass of sprat consumed by common murre chicks at Stora Karlsö during the 1970s (13.3 g; Hedgren 1976) was similar to weight-at-age-4 for sprat during that time period (13.4 g; ICES 2010). However, we also used information from weight-at-age classes 2, 3 and 5. The fish size estimates in combination with available length data (Kondratjeva 1993) indicate that Baltic sprat of all age-classes can be fed to the chick. In some years, the smallest clupeids fed to the chicks may have been relatively large 1 yr old sprat, but these probably constituted no more than a minor share of the diet. As sprat $6 \mathrm{yr}$ and older form only a small part of the stock, we conclude that it is unlikely they constituted a large proportion of the diet. Due to the similarity in inter-annual weight-at-age trends and to limit the number of explanatory variables to test, we decided to use age classes 2 to 5 only.

\section{Physical factors}

We assessed possible confounding relationships with physical factors by modelling fledging success, feeding frequency and trip duration, respectively, as response variables, and winter North Atlantic Oscillation (NAO) index and anomalies from average air temperatures in June as explanatory variables. NAO is a large-scale climate index that in winter (January and February) is correlated to Baltic Sea ice cover and water temperature during spring (MacKenzie \& Köster 2004), and is thus assumed to reflect climatic conditions experienced by murres during the prebreeding period. Monthly NAO data were obtained from the Climate Research Unit at the University of East Anglia (e.g. Jones et al. 1997, Osborn 2004), available at www.cru.uea.ac.uk/cru/data/nao/. Average air temperatures were from Visby airport, the closest weather station, and were provided by the Swedish Meteorological and Hydrological Institute. Chick fledging mass was negatively correlated with June air temperature anomalies during the 1990s (Österblom et al. 2001) and we thus assume that temperature anomalies reflect conditions during chickrearing. Long-term average air temperature was calculated from 1961 to 2010.

\section{Statistical analysis}

Statistical analyses were performed using $\mathrm{R}$ version 2.11.0 (R Development Core Team 2010). Bird variables were modelled as response variables and sprat, or physical, variables as explanatory variables. Trip duration data were $\ln$-transformed to improve model fit. However, similar results were obtained 
using non-transformed data. The physical variables were not correlated and, hence, they were included in the same models. Interactions between physical variables were not considered due to the limited number of data points. Sprat variables were significantly and strongly correlated $(\mathrm{r}<-0.6$ for correlations between abundance and each set of weightat-age estimates, $\mathrm{r}>0.8$ for correlations between weight-at-age of different age classes). Due to the issue of colinearity, relationships with sprat variables were investigated in separate models. The possible effects of interactions between sprat variables were thus not studied. $\chi^{2}$-tests were applied to categorical data. Linear regression was used for continuous response variables. Generalised linear models (GLM) were used when the response variable contained data on proportions (i.e. fledging success). When overdispersion (dispersal parameter > 1.5) was detected when a GLM was used, the standard errors were corrected by using a quasi-GLM, and an overdispersion parameter was added to the variance of the response variable, as recommended by Zuur et al. (2009). We did not select a particular model when several models with sprat weight-at-age were supported, as we consider this to be of limited ecological relevance given the birds' consumption of all age classes included in the models.

\section{RESULTS}

Common murre fledging success varied between 0.88 and 0.97 during the study (Fig. 1a). Chicks that did not fledge were observed dead or missing at an average $( \pm \mathrm{SD})$ age of $6.8 \pm 4.9 \mathrm{~d}(\mathrm{n}=34)$. There were positive relationships between fledging success and
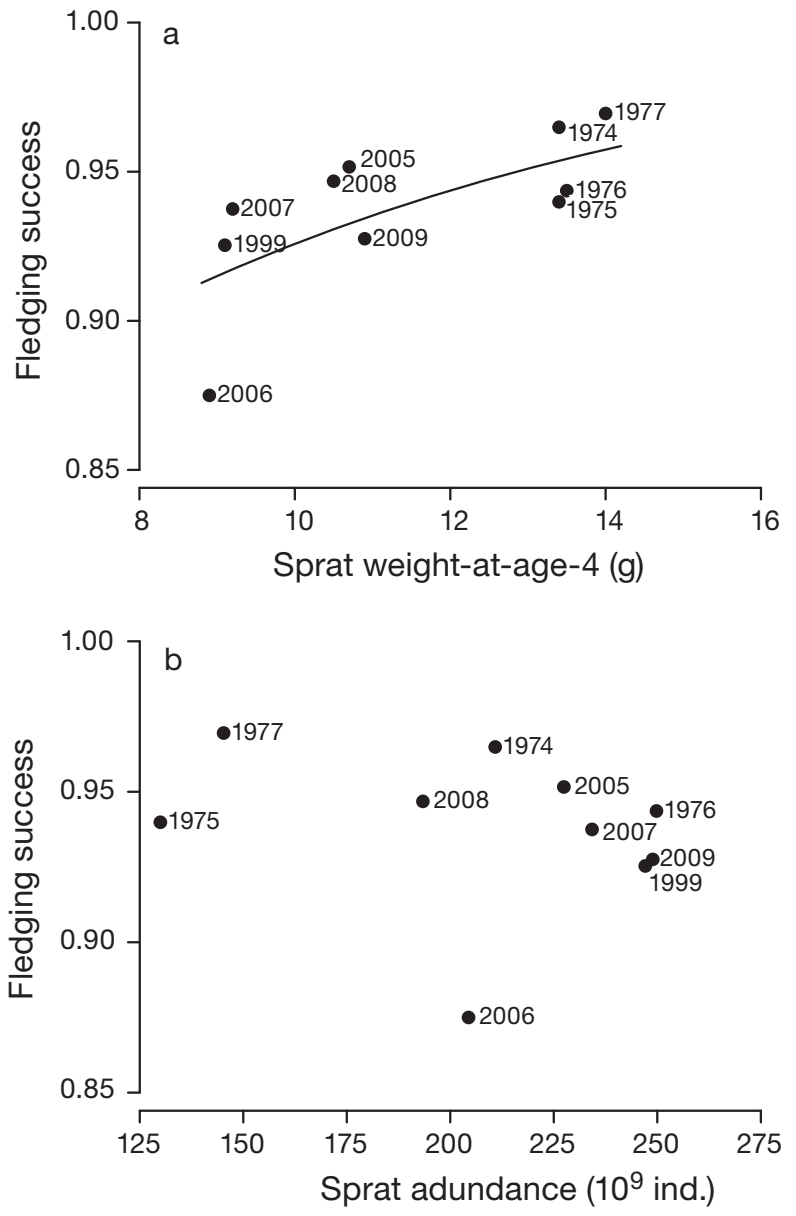

Fig. 1. Uria aalge and Sprattus sprattus. Mean annual fledging success (chicks fledged divided by chicks hatched) for common murres on Stora Karlsö, Baltic Sea, in various years in relation to (a) mean sprat weight-at-age-4 and (b) sprat abundance in the Baltic Sea (ICES subdivisions 22 to 32). The line in (a) indicates the relationship predicted by the generalised linear model. The 1970 s data on fledging success are from Hedgren (1980)

Table 1. Uria aalge and Sprattus sprattus. Relationships between common murre fledging success, chick provisioning variables and sprat abundance and weight-at-age. Generalised linear models (GLM) were used for fledging success; linear regression was used for other response variables. Significant relationships are shown in bold. Sprat data from ICES (2010). ns = not significant

\begin{tabular}{|c|c|c|c|c|}
\hline \multirow[t]{2}{*}{ Explanatory variable } & \multirow{2}{*}{ Fledging success } & \multirow{2}{*}{$\begin{array}{l}\text { Response va } \\
\text { Trip duration, ln-transformed }\end{array}$} & \multirow{2}{*}{ Size of fish } & \multirow[b]{2}{*}{ No. of fish fed to chick } \\
\hline & & & & \\
\hline Years & $1974-77,1999,2005-09$ & $1998,2005-09$ & 2005-09 & $1998,2002,2005-09$ \\
\hline \multicolumn{5}{|l|}{ Sprat weight-at-age } \\
\hline 2 & $z=2.07, p<0.04$ & $F_{1,4}=0.59, \mathrm{~ns}$ & $F_{1,3}=0.70, \mathrm{~ns}$ & $F_{1,5}=0.10, \mathrm{~ns}$ \\
\hline 3 & $z=2.54, p<0.02$ & $F_{1,4}=0.33, \mathrm{~ns}$ & $F_{1,3}=0.30, \mathrm{~ns}$ & $F_{1,5}=0.15, \mathrm{~ns}$ \\
\hline 4 & $z=2.67, p<0.01$ & $F_{1,4}=1.38, \mathrm{~ns}$ & $F_{1,3}=3.39, \mathrm{~ns}$ & $F_{1,5}=0.49, \mathrm{~ns}$ \\
\hline 5 & $z=1.9, p<0.05$ & $F_{1,4}=0.01, \mathrm{~ns}$ & $F_{1,3}=0.33, \mathrm{~ns}$ & $F_{1,5}=0.04, \mathrm{~ns}$ \\
\hline Sprat abundance & $\begin{array}{l}t=-1.01, \mathrm{~ns} \\
\text { (Quasi-GLM) }\end{array}$ & $\begin{aligned} F_{1,4}= & 15.69, p<0.017 \\
& r^{2}=0.797\end{aligned}$ & $F_{1,3}=0.74, \mathrm{~ns}$ & $F_{1,5}=0.38, \mathrm{~ns}$ \\
\hline
\end{tabular}


Table 2. Uria aalge and Sprattus sprattus. Relationships between fledging success, trip duration and no. of fish fed per chick per day and physical variables. Significant relationships are shown in bold. Monthly North Atlantic Oscillation (NAO) data are from the Climate Research Unit, University of East Anglia. Average air temperatures $(T)$ in June (anomalies from long-term average air temperature in June at Visby airport, Gotland, Baltic Sea) were provided by the Swedish Meteorological and Hydrological Institute. GLM = generalised linear model, ns = not significant

\begin{tabular}{|c|c|c|c|}
\hline \multirow[t]{2}{*}{ Explanatory variable(s) } & \multicolumn{3}{|c|}{ - Response variable- } \\
\hline & $\begin{array}{l}\text { Fledging success } \\
\text { Quasi-GLM }\end{array}$ & $\begin{array}{c}\text { Trip duration, ln-transformed } \\
\text { Linear regression }\end{array}$ & $\begin{array}{l}\text { No. of fish fed to chick } \\
\text { Linear regression }\end{array}$ \\
\hline Years & $1974-77,1999,2005-09$ & $1998,2005-09$ & $1998,2002,2005-09$ \\
\hline $\mathrm{NAO}_{\text {Jan-Feb }}+T$ & $t=0.02, t=0.13, \mathrm{~ns}$ & $F_{2,3}=0.46, \mathrm{~ns}$ & $F_{2,4}=12.6, p<0.05$ \\
\hline $\mathrm{NAO}_{\text {Jan-Feb }}$ & $t=0.01, \mathrm{~ns}$ & $F_{1,4}=0.21, \mathrm{~ns}$ & $F_{1,5}=4.64, \mathrm{~ns}$ \\
\hline$T$ & $t=0.14, \mathrm{~ns}$ & $F_{1,4}=1.06, \mathrm{~ns}$ & $F_{1,5}=0.56, \mathrm{~ns}$ \\
\hline
\end{tabular}

weight-at-age of sprat (Table 1, Fig. 1a). There was no significant relationship between fledging success and sprat abundance (Table 1, Fig. 1b). No relationship was detected between fledging success and January-February NAO or anomalies from average air temperature in June (Table 2).

Mean trip duration for successful foraging trips varied significantly between years (ANOVA: $F_{5,1083}=$ $2.86, \mathrm{p}=0.014)$ and was well explained by sprat abundance (Table 1), with longer trips observed in years with lower abundance (Fig. 2). No significant relationships were found between trip duration and mean weight-at-age of 2 to $5 \mathrm{yr}$ old sprat (Table 1). Neither was any relationship with physical variables detected (Table 2). For pairs with a chick aged 7 to $15 \mathrm{~d}$ the time the 2 parents spent together on the ledge with the chick was analysed as the percentage of time spent with mates during the watch, to avoid age-related bias (see 'Materials and methods'). Parents spent on average $18 \%$ of the day together $\left(\mathrm{n}_{\text {all years }}=118\right.$ pair-days, minimum: $10 \%$ [third watch in $2008, \mathrm{n}=7$ pairs], maximum: $28 \%$ [first watch in $2005, \mathrm{n}=11$ pairs]).

Number of fish fed per chick (aged 7 to $15 \mathrm{~d}$ ) per day showed no significant differences between years (ANOVA: $F_{1,211}=2.59, \mathrm{p}=0.11$ ). No relationship between mean annual feeding rates and sprat total abundance, or sprat weight-at-age, was found (Table 1). A model with January-February NAO and anomalies from average air temperature in June explained $80 \%$ of the variation in mean number of fish fed per chick per day. However, there were no significant relationships in models with only 1 explanatory variable (Table 2 ).

Inter-annual differences in size of fish were analysed for chicks of $4 \mathrm{~d}$ of age or older, as younger chicks generally received smaller fish. The distribution in 4 size categories differed significantly between years $\left(\chi^{2}=43.3, \mathrm{df}=12, \mathrm{p}<0.001\right.$; Table 3$)$.
After grouping the size categories into small (Size 1 and 2) and large (Size 3 and 4), the results were nearsignificant $\left(\chi^{2}=9.08, \mathrm{df}=4, \mathrm{p}=0.059\right)$, where clupeids were indicated to have been larger in 2005 and
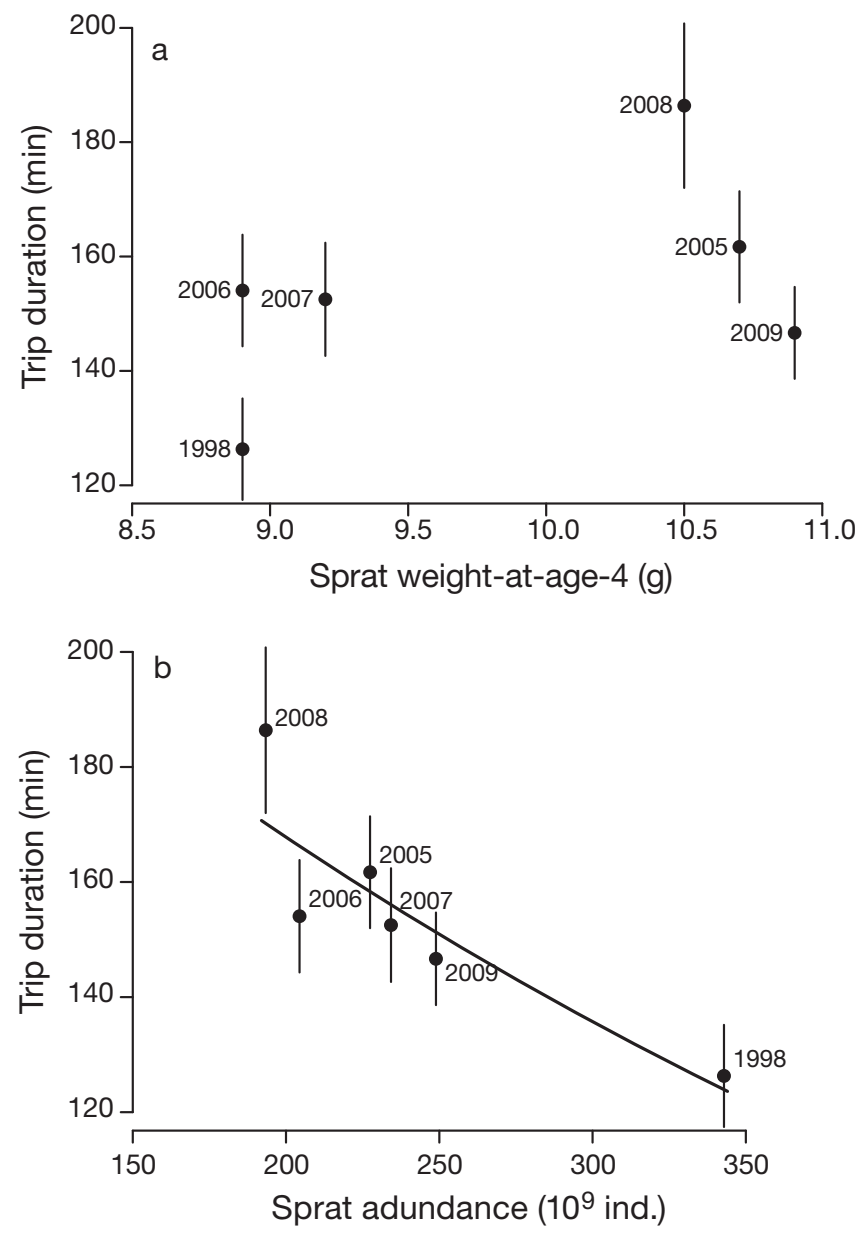

Fig. 2. Uria aalge and Sprattus sprattus. Mean trip duration for common murres breeding on Stora Karlsö in various years in relation to (a) mean sprat weight-at-age-4 and (b) sprat abundance in the Baltic Sea (ICES subdivisions 22 to 32). The line in (b) indicates the relationship predicted by the linear regression. Error bars indicate SE 
Table 3. Uria aalge and Sprattus sprattus. Percentage by number of clupeids assigned to size categories when delivered to common murre chicks, age $4 \mathrm{~d}$ and older. For details of bill length see 'Materials and methods: Chick provisioning'. The number of prey items (or sample size) is given in parentheses

\begin{tabular}{|c|c|c|c|c|c|}
\hline \multirow[t]{2}{*}{ Year } & \multicolumn{4}{|c|}{-Size category } & \multirow[b]{2}{*}{ Total (n) } \\
\hline & $\begin{array}{c}1 \\
\text { ( } \leq 2 \text { bill lengths) }\end{array}$ & $\begin{array}{c}2 \\
\left(\sim 2 \frac{1}{3} \text { bill lengths }\right)\end{array}$ & $\begin{array}{c}3 \\
\left(\sim 2 \frac{2}{3} \text { bill lengths }\right)\end{array}$ & $\begin{array}{c}4 \\
\text { ( } \geq 3 \text { bill lengths) }\end{array}$ & \\
\hline 2005 & $15(35)$ & $42(97)$ & $32(75)$ & $10(24)$ & 231 \\
\hline 2006 & $19(44)$ & 43 (98) & $32(74)$ & $6(14)$ & 230 \\
\hline 2007 & $17(33)$ & $51(98)$ & 27 (53) & $5(10)$ & 194 \\
\hline 2008 & $4(4)$ & $48(50)$ & $42(44)$ & $6(6)$ & 104 \\
\hline 2009 & $8(26)$ & 55 (181) & 33 (108) & $4(14)$ & 329 \\
\hline
\end{tabular}

2008 compared to the other years. No associations were found between size of delivered clupeids, measured in bill lengths, and sprat weight-at-age or sprat abundance (Table 1). Ordinal logistic regression was first applied to examine possible associations between size of delivered clupeids and sprat parameters, but the assumption of parallel slopes (proportional odds) was not met, and so no conclusions could be drawn from this analysis. Size categories converted to bill lengths may yield results that are biased low (see 'Material and methods'), but we prefer this option, since we find that the interpretation of a linear regression is more intuitive than applying a multinomial logistic regression in this case.

\section{DISCUSSION}

Food quality (sprat weight-at-age), but not quantity (sprat abundance), was positively related to common murre fledging success. The adjustments of parental effort in relation to quality and quantity showed the opposite pattern: no relationships between parental effort and sprat weight-at-age but a negative relationship between sprat abundance and the duration of foraging trips.

Central-place foraging implies high energy expenditures for parents and limits provisioning rates (Orians \& Pearson 1979). The digestion efficiency in seabirds decreases with lower lipid (i.e. energy) content (Brekke \& Gabrielsen 1994), and energy content in several forage-fish species, including sprat, shows positive correlations with size (Hislop et al. 1991, Hilton et al. 1998). Geographically constrained seabirds may have limited capacity to adapt to changing energy content of their prey. Such constraints are likely especially evident for single-prey loaders like murres (Bradstreet \& Brown 1985), with a relatively fast, ineffective and inflexible digestive process (Hilton et al. 2000a,b).
Baltic murres are dependent on sprat as a food source (Hedgren 1976, Lyngs \& Durinck 1998) and have limited ability to switch to other prey items. The only available substitute, Baltic herring, has lower energy content (Hjelm et al. 2006) in the size range suitable for murres (Bradstreet \& Brown 1985). Decreased weight-at-age of sprat seems to be a probable cause of the observed lower fledging success in Baltic murres, analogous to previously published observations suggesting such a link also to chick fledging mass (Österblom et al. 2001, 2006). Breeding success in North Sea murres is strongly associated with length of preferred prey, at least when prey availability exceeds threshold levels (Wanless et al. 2005, Frederiksen et al. 2006, Ashbrook et al. 2010). Sprat was relatively abundant during our study period and the relationships detected in the Baltic Sea may be different in situations when food availability is limited.

Predation from herring gulls, human disturbance, the proportion of inexperienced breeders with lower success rates, effects of population density changes and climatic variables are factors that could potentially be considered as alternative explanations for the observed changes in fledging success and offspring provisioning (Hedgren 1980, Österblom \& Olsson 2002, Beale \& Monaghan 2004, Kokko et al. 2004). All available information, including field observations and results, suggests that none of these factors have influenced the observed relationships. The significant relationship between feeding rates, NAO and temperature anomalies is potentially interesting, but we lack knowledge about relationships between these variables and e.g. adult condition and prey accessibility, which could provide mechanistic explanations. The results may also be a statistical artefact due to low sample size.

We found no relationship between fledging success and food quantity, analogous to the findings of Burger \& Piatt (1990), who documented no impacts 
on fledging success for Canadian murres despite 10fold changes in prey abundance and density. Flexible time budgets allowed parents to buffer prey variability to sustain feeding rates, provided that prey availability did not fall below threshold levels (Burger \& Piatt 1990, see also Uttley et al. 1994, Ashbrook et al. 2010). Such parental buffering appears to be a plausible explanation for our observed uniform feeding rates despite differences in sprat abundance. In turn, foraging trips were of longer duration when abundance was lower.

It is also possible that the absence of a relationship between fledging success and food quantity is due to the measure of quantity used. Estimates of sprat abundance are only available at the scale of the Baltic Sea (ICES 2010), without taking account of intra-annual changes in distribution. This could potentially result in spatial and temporal mismatches with our seabird data. However, the observed relationship between sprat abundance and foraging trip duration suggests that sprat estimates are conducted at a relevant scale.

The positive relationship between fledging success and sprat weight-at-age suggests that it would be adaptive for murres to respond to the variation in food quality observed during this period. Adaptive responses would include e.g. higher feeding frequency, delivery of larger fish or efforts aiming at finding fatter prey items reflected in longer duration of foraging trips during periods with lower sprat weight-at-age (cf. Monaghan et al. 1994, Uttley et al. 1994). While acknowledging the low sample sizes for chick feeding parameters and the relatively coarse method of measuring size of delivered fish, we find no such indications in our study.

Adjustment of effort requires flexibility in time budgets of parents. The duration of foraging trips and the proportion of time spent with mates in this colony were in most years comparable to trips recorded in other colonies with good feeding conditions (Burger \& Piatt 1990, Zador \& Piatt 1999, Davoren \& Montevecchi 2003). This would suggest that parental birds at Stora Karlsö were able to invest more time or effort in foraging (Burger \& Piatt 1990), but apparently did not do so. Such an investment in offspring survival would only be adaptive if not negatively affecting future opportunities (Lack 1968). Adult survival was very high in this colony (annual survival was > 93\% from 1997 to 2009; Österblom et al. 2004, authors' unpubl. data) suggesting that parents did not compromise their own survival for the provisioning of chicks.

Adjusting effort requires further that parents are able to recognise the decrease in energy delivery or meal size, or lower chick growth rate, possibly manifested in symptoms of starvation. Adult birds are under different constraints than chicks (Bradstreet \& Brown 1985). Lower mass of individual prey may not influence adult birds, provided food is abundant. Chicks, however, with a smaller digestive capacity, could become satiated without receiving sufficient energy. Such differences can misguide adults in judging effort needed to provision the chick with enough energy.

The results of the present study indicate that there was room for adjustments of parental effort, which could have counteracted the observed impacts of a lower food quality, but no signs of such adjustments were found. The implicit relationships between chick food intake, food quality and fledging success was rarely observed directly, since the dawn-to-duskwatches by necessity included a limited number of pairs and, thus, very few chicks observed during these watches were later found to have died. However, in the years with lowest fledging success, casual observations of dead chicks on breeding ledges indicated higher chick mortality in these years (authors' pers. obs.).

The observed variation in fledging success is not very large (cf. Harris \& Wanless 1988, Burger \& Piatt 1990) and will probably have a limited impact at the population level. Reproductive output in this colony is comparable with other murre colonies during periods with stable or increasing populations (e.g. Harris \& Wanless 1988). Moreover, high juvenile and adult survival is indicated by other studies (Österblom et al. 2004, Hjernquist \& Hjernquist 2010, authors' unpubl. data), and several Baltic Sea colonies appear to have been stable or increased in recent decades (Staav 2009, Hjernquist \& Hjernquist 2010, authors' unpubl. data).

Studies of offspring provisioning and population parameters in relation to food quality and quantity are not new (e.g. Österblom et al. 2008), but to our knowledge this is the first case where impacts of both quality and quantity have been observed simultaneously, and their effects separated. Seabirds are increasingly used as indicators of changes in marine ecosystems (e.g. Furness \& Camphuysen 1997, Parsons et al. 2008, Durant et al. 2009, Ottersen et al. 2011). Knowledge of the way prey quality and quantity can influence different lifehistory parameters is important for the choice and interpretation of indicators. Murre breeding success, or fledging success alone, may be one sufficiently fast and inexpensive indicator. However, we want to stress the importance of examining a num- 
ber of both longer- and shorter-term population parameters to also understand interacting impacts of variation in food quality, quantity and accessibility.

In the future, a potentially increasing demand for forage fish to fishmeal markets (Alder et al. 2008), changing stocks of cod and seals (Harding \& Härkönen 1999) and climate-induced changes impacting lower trophic levels in the Baltic Sea food web (Möllmann et al. 2009) are expected to further change sprat quantity and quality (Casini et al. 2006, 2008). Human activities may thus cause cascading effects on common murre life-history parameters. Careful monitoring that informs management decisions is essential for sustaining seabird populations and for successful implementation of ecosystem-based approaches in management of marine systems.

Acknowledgements. We thank E. Enekvist, E. Kylberg, E. Willerström and numerous field assistants and volunteers for their highly valuable contribution to the fieldwork. S. Hedgren kindly gave us access to the 1970s murre breeding data. The International Council for the Exploration of the Seas (ICES) kindly gave us permission to cite the ICES WGBFAS report. The Swedish Meteorological and Hydrological Institute provided monthly air-temperature data. We thank 4 anonymous reviewers for constructive comments on an earlier version of this manuscript. This study was funded by WWF Sweden (www.wwf.se), Mistra (www.mistra.org), the Swedish Environmental Protection Agency (www. naturvardsverket.se) (H.Ö.), Stiftelsen Marcus och Amalia Wallenbergs minnesfond (project MAW 2008.0037) (M.K.) and Formas (www.formas.se) (M.K.). Karlsö Jagt- och Djurskyddsförenings AB provided logistical support.

\section{LITERATURE CITED}

Alder J, Campbell B, Karpouzi V, Kaschner K, Pauly D (2008) Forage fish: from ecosystems to markets. Annu Rev Environ Resour 33:153-166

Alheit J, Möllmann C, Dutz J, Kornilovs G, Loewe P, Mohrholz V, Wasmund N (2005) Synchronous ecological regime shifts in the central Baltic and the North Sea in the late 1980s. ICES J Mar Sci 62:1205-1215

Alverson DL (1992) A review of commercial fisheries and the Steller sea lion (Eumetopias jubatus): the conflict arena. Rev Aquat Sci 6:203-256

Ashbrook K, Wanless S, Harris MP, Hamer KC (2008) Hitting the buffers: conspecific aggression undermines benefits of colonial breeding under adverse conditions. Biol Lett 4:630-633

Ashbrook K, Wanless S, Harris MP, Hamer KC (2010) Impacts of poor food availability on positive density dependence in a highly colonial seabird. Proc R Soc B Biol Sci 277:2355-2360

Beale CM, Monaghan P (2004) Human disturbance: people as predation-free predators? J Appl Ecol 41:335-343

Bradstreet MSW, Brown RGB (1985) Feeding ecology of the Atlantic Alcidae. In: Nettleship DN, Birkhead TR (eds)
The Atlantic Alcidae: the evolution, distribution and biology of the auks inhabiting the Atlantic Ocean and adjacent water areas. Academic Press, London, p 263-318

Brekke B, Gabrielsen GW (1994) Assimilation efficiency of adult kittiwakes and Brunnich guillemots fed capelin and Arctic cod. Polar Biol 14:279-284

Burger AE, Piatt JF (1990) Flexible time budgets in breeding common murres: buffers against variable prey abundance. Stud Avian Biol 14:71-83

Casini M, Cardinale M, Hjelm J (2006) Inter-annual variation in herring, Clupea harengus, and sprat, Sprattus sprattus, condition in the central Baltic Sea: What gives the tune? Oikos 112:638-650

Casini M, Lovgren J, Hjelm J, Cardinale M, Molinero JC, Kornilovs G (2008) Multi-level trophic cascades in a heavily exploited open marine ecosystem. Proc R Soc B Biol Sci 275:1793-1801

Casini M, Hjelm J, Molinero JC, Lovgren J and others (2009) Trophic cascades promote threshold-like shifts in pelagic marine ecosystems. Proc Natl Acad Sci USA 106:197-202

Casini M, Bartolino V, Molinero JC, Kornilovs G (2010) Linking fisheries, trophic interactions and climate: threshold dynamics drive herring Clupea harengus growth in the central Baltic Sea. Mar Ecol Prog Ser 413: 241-252

Cheung WWL, Lam VWY, Sarmiento JL, Kearney K, Watson R, Pauly D (2009) Projecting global marine biodiversity impacts under climate change scenarios. Fish Fish 10: 235-251

> Davoren GK, Montevecchi WA (2003) Consequences of foraging trip duration on provisioning behaviour and fledging condition of common murres Uria aalge. J Avian Biol 34:44-53

Deutsch L, Graslund S, Folke C, Troell M, Huitric M, Kautsky N, Lebel L (2007) Feeding aquaculture growth through globalization: exploitation of marine ecosystems for fishmeal. Glob Environ Change 17:238-249

> Durant JM, Hjermann DØ, Frederiksen M, Charrassin JB and others (2009) Pros and cons of using seabirds as ecological indicators. Clim Res 39:115-129

- Eero M, MacKenzie BR, Koster FW, Gislason H (2011) Multidecadal responses of a cod (Gadus morhua) population to human-induced trophic changes, fishing, and climate. Ecol Appl 21:214-226

Elliott KH, Davoren GK, Gaston AJ (2008) Sources of bias in observations of murre provisioning behavior. J Field Ornithol 79:298-307

FAO (Food and Agriculture Organization of the United Nations) (2010) The state of world fisheries and aquaculture 2010. FAO, Rome

Frank KT, Petrie B, Choi JS, Leggett WC (2005) Trophic cascades in a formerly cod-dominated ecosystem. Science 308:1621-1623

Frederiksen M, Edwards M, Richardson AJ, Halliday NC, Wanless S (2006) From plankton to top predators: bottom-up control of a marine food web across four trophic levels. J Anim Ecol 75:1259-1268

Fritz LW, Hinckley S (2005) A critical review of the regime shift-'junk food'-nutritional stress hypothesis for the decline of the western stock of Steller sea lion. Mar Mamm Sci 21:476-518

Furness RW, Camphuysen CJ (1997) Seabirds as monitors of the marine environment. ICES J Mar Sci 54:726-737

Furness RW, Tasker ML (2000) Seabird-fishery interactions: quantifying the sensitivity of seabirds to reductions in 
sandeel abundance, and identification of key areas for sensitive seabirds in the North Sea. Mar Ecol Prog Ser 202:253-264

Harding KC, Härkönen TJ (1999) Development in the Baltic grey seal (Halichoerus grypus) and ringed seal (Phoca hispida) populations during the 20th century. Ambio 28: 619-627

Hario M (1982) On the size and recruitment of a peripheral breeding colony of the guillemot Uria aalge. Ornis Fenn 59:193-194

Harris MP, Wanless S (1988) The breeding biology of guillemots Uria aalge on the Isle of May over a six year period. Ibis 130:172-192

Hedgren S (1976) On the food of the guillemot Uria aalge at the island of Stora Karlsö, the Baltic Sea. Vår fågelvärld 35:287-290

Hedgren S (1980) Reproductive success of guillemots Uria aalge on the island of Stora Karlsö. Ornis Fenn 57:49-57

Hedgren S, Linnman A (1979) Growth of guillemot Uria aalge chicks in relation to time of hatching. Ornis Scand 10:29-36

Hilton GM, Houston DC, Furness RW (1998) Which components of diet quality affect retention time of digesta in seabirds? Funct Ecol 12:929-939

Hilton GM, Furness RW, Houston DC (2000a) A comparative study of digestion in North Atlantic seabirds. J Avian Biol 31:36-46

> Hilton GM, Furness RW, Houston DC (2000b) The effects of diet switching and mixing on digestion in seabirds. Funct Ecol 14:145-154

> Hislop JRG, Harris MP, Smith JGM (1991) Variation in the calorific value and total energy content of the lesser sandeel (Ammodytes marinus) and other fish preyed on by seabirds. J Zool (Lond) 224:501-517

> Hjelm J, Hultgren M, Cardinale M (2006) Water uptake in herring (Clupea harengus) and sprat (Sprattus sprattus) as a function of area, salinity and fat content. Fish Res 81: 94-99

Hjernquist B, Hjernquist MB (2010) The effects of quantity and quality of prey on population fluctuations in three seabird species. Bird Study 57:19-25

Holmström KE, Järnberg U, Bignert A (2005) Temporal trends of PFOS and PFOA in guillemot eggs from the Baltic Sea, 1968-2003. Environ Sci Technol 39:80-84

ICES (2010) Report of the Baltic Fisheries Assessment Working Group (WGBFAS), 15-22 April 2010. ICES, Copenhagen

> Jackson JBC, Kirby MX, Berger WH, Bjorndal KA and others (2001) Historical overfishing and the recent collapse of coastal ecosystems. Science 293:629-637

> Jones PD, Jonsson T, Wheeler D (1997) Extension to the North Atlantic Oscillation using early instrumental pressure observations from Gibraltar and south-west Iceland. Int J Climatol 17:1433-1450

Kokko H, Harris MP, Wanless S (2004) Competition for breeding sites and site-dependent population regulation in a highly colonial seabird, the common guillemot Uria aalge. J Anim Ecol 73:367-376

Kondratjeva N (1993) Biochemical and morphophysiological parameters of Baltic sprat in relation to age and annual cycle periods. ICES CM 1993/J:25. ICES, Copenhagen

Lack D (1968) Ecological adaptations for breeding in birds. Methuen, London

> Ludwig D, Hilborn R, Walters C (1993) Uncertainty, resource exploitation, and conservation: lessons from history.
Science 260:17-36

Lyngs P (1993) Colony interchange in Baltic guillemots Uria aalge. Dansk Ornitol Foren Tidsskr 87:247-250

Lyngs P, Durinck J (1998) Diet of guillemots Uria aalge in the central Baltic Sea. Dansk Ornitol Foren Tidsskr 92: 197-200

> MacKenzie BR, Köster FW (2004) Fish production and climate: sprat in the Baltic Sea. Ecology 85:784-794

MacKenzie BR, Alheit J, Conley DJ, Holm P, Kinze CC (2002) Ecological hypotheses for a historical reconstruction of upper trophic level biomass in the Baltic Sea and Skagerrak. Can J Fish Aquat Sci 59:173-190

> Möllmann C, Kornilovs G, Fetter M, Köster FW (2005) Climate, zooplankton, and pelagic fish growth in the central Baltic Sea. ICES J Mar Sci 62:1270-1280

Möllmann C, Muller-Karulis B, Kornilovs G, St John MA (2008) Effects of climate and overfishing on zooplankton dynamics and ecosystem structure: regime shifts, trophic cascade, and feedback loops in a simple ecosystem. ICES J Mar Sci 65:302-310

Möllmann C, Diekmann R, Muller-Karulis B, Kornilovs G, Plikshs M, Axe P (2009) Reorganization of a large marine ecosystem due to atmospheric and anthropogenic pressure: a discontinuous regime shift in the Central Baltic Sea. Glob Change Biol 15:1377-1393

Monaghan P, Walton P, Wanless S, Uttley JD, Burns MD (1994) Effects of prey abundance on the foraging behavior, diving efficiency and time allocation of breeding guillemots Uria aalge. Ibis 136:214-222

Naylor RL, Goldburg RJ, Primavera JH, Kautsky N and others (2000) Effect of aquaculture on world fish supplies. Nature 405:1017-1024

Naylor RL, Hardy RW, Bureau DP, Chiu A and others (2009) Feeding aquaculture in an era of finite resources. Proc Natl Acad Sci USA 106:15103-15110

Orians GH, Pearson NE (1979) On the theory of central place foraging. In: Horn DJ, Mitchell RD, Stairs GR (eds) Analysis of ecological systems. Ohio State University Press, Columbus, OH, p 154-177

Osborn TJ (2004) Simulating the winter North Atlantic Oscillation: the roles of internal variability and greenhouse gas forcing. Clim Dyn 22:605-623

Österblom H, Olsson O (2002) Changes in feeding behaviour and reproductive success in the common guillemot Uria aalge on the island of Stora Karlsö. Ornis Svec 12: 53-62

> Österblom H, Bignert A, Fransson T, Olsson O (2001) A decrease in fledging body mass in common guillemot Uria aalge chicks in the Baltic Sea. Mar Ecol Prog Ser 224:305-309

Österblom H, Van der Jeugd HP, Olsson O (2004) Adult survival and avian cholera in common guillemots Uria aalge in the Baltic Sea. Ibis 146:531-534

Österblom H, Casini M, Olsson O, Bignert A (2006) Fish, seabirds and trophic cascades in the Baltic Sea. Mar Ecol Prog Ser 323:233-238

Österblom H, Olsson O, Blenckner T, Furness RW (2008) Junk-food in marine ecosystems. Oikos 117:967-977

Ottersen G, Olsen E, van der Meeren GI, Dommasnes A, Loeng $H$ (2011) The Norwegian plan for integrated ecosystem-based management of the marine environment in the Norwegian Sea. Mar Policy 35:389-398

> Parsons M, Mitchell I, Butler A, Ratcliffe N, Frederiksen M, Foster S, Reid JB (2008) Seabirds as indicators of the marine environment. ICES J Mar Sci 65:1520-1526 
Pauly D, Alder J, Bennett E, Christensen V, Tyedmers P, Watson R (2003) The future for fisheries. Science 302: 1359-1361

Peterz M, Blomqvist S (2010) Connectivity and age distribution of the Baltic common guillemot Uria aalge population: evidence from morphometry and ringing recoveries. Ardea 98:169-178

Piatt JF, Harding AMA, Shultz M, Speckman SG, van Pelt TI, Drew GS, Kettle AB (2007) Seabirds as indicators of marine food supplies: Cairns revisited. Mar Ecol Prog Ser 352:221-234

R Development Core Team (2010) R: a language and environment for statistical computing. R Foundation for Statistical Computing, Vienna

Sethi SA, Branch TA, Watson R (2010) Global fishery development patterns are driven by profit but not trophic level. Proc Natl Acad Sci USA 107:12163-12167

Sigler MF, Tollit DJ, Vollenweider JJ, Thedinga JF and others (2009) Steller sea lion foraging response to seasonal changes in prey availability. Mar Ecol Prog Ser 388: 243-261
Staav R (2009) Sillgrisslan allt vanligare i Stockholms skärgård. Fåglar i Stockholmstrakten 38:105-111

Trites AW, Donnelly CP (2003) The decline of Steller sea lions Eumetopias jubatus in Alaska: a review of the nutritional stress hypothesis. Mammal Rev 33:3-28

Uttley JD, Walton P, Monaghan P, Austin G (1994) The effects of food abundance on breeding performance and adult time budgets of guillemots Uria aalge. Ibis 136: 205-213

> Wanless S, Harris MP, Redman P, Speakman JR (2005) Low energy values of fish as a probable cause of a major seabird breeding failure in the North Sea. Mar Ecol Prog Ser 294:1-8

Zador SG, Piatt JF (1999) Time-budgets of common murres at a declining and increasing colony in Alaska. Condor 101:149-152

Zuur AF, Ieno EN, Walker NJ, Saveliev AA, Smith GM (2009) Mixed effects models and extensions in ecology with R. In: Gail M, Krickeberg K, Samet JM, Tsiatis A, Wong W (eds) Statistics for biology and health. Springer, New York, NY

\section{Appendix 1. Chick diet}

Table A1. Uria aalge. Number of fish of different types delivered at breeding sites during 3 annual dawn-to-dusk-watches (all years except 2004) and occasional observations during the chick-rearing period (2004)

\begin{tabular}{|lcccccccc|}
\hline Species & 1998 & 2002 & 2004 & 2005 & 2006 & 2007 & 2008 & 2009 \\
\hline Clupeid & 332 & 229 & 176 & 259 & 245 & 241 & 139 & 356 \\
Sandeel Ammodytes spp. & 3 & 4 & 14 & 0 & 2 & 2 & 4 & 3 \\
Three-spined stickleback Gasterosteus aculeatus & 0 & 0 & 0 & 1 & 0 & 1 & 1 & 0 \\
Unknown & 9 & 0 & 2 & 0 & 0 & 4 & 4 & 2 \\
\end{tabular}

Editorial responsibility: John Piatt, Anchorage, Alaska, USA
Submitted: March 28, 2011; Accepted: September 22, 2011 Proofs received from author(s): December 16, 2011 